\title{
SERUM CLARA CELL PROTEIN AS AN INDICATOR OF PULMONARY IMPAIRMENT IN OCCUPATIONAL EXPOSURE AT ALUMINUM FOUNDRY
}

\section{TADEUSZ HAŁATEK ${ }^{1}$, MAŁGORZATA TRZCINKA-OCHOCKA ${ }^{2}$, WANDA MATCZAK ${ }^{2}$, and JACEK GRUCHAŁA ${ }^{3}$}

${ }^{1}$ Department of Toxicology and Carcinogenesis

${ }^{2}$ Department of Chemical and Dust Hazards

${ }^{3}$ Department of Occupational Diseases

Nofer Institute of Occupational Medicine

Łódź, Poland

\begin{abstract}
Objectives: Although some of the exposures in aluminum (Al) smelting have been well characterized, and respiratory disorders in aluminum production workers are well known, the relationship between internal aluminum loads and appropriate lung biomarkers have not been elucidated. The aim of our work was to carry out a comprehensive investigation in workers employed in the Aluminum Foundry Casting Department with special reference to currently existing hygiene standards, known as threshold limit values (TLV) based on aluminum effects on the respiratory system. The measurement of serum anti-inflammatory Clara cell protein (CC16) was employed as a peripheral marker of the lung epithelium function. Materials and Methods: A group of 50 casting smelters, 5 locksmiths, 11 sawyers and auxiliary workers exposed to dust containing $14 \%$ of aluminum, and a group of 42 controls were examined. Respiratory function tests were performed and forced volume capacity $(\mathrm{FVC})$, forced expiratory volume in $1 \mathrm{~s}\left(\mathrm{FEV}_{1}\right)$, forced expiratory volume in the first percent $\left(\mathrm{FEV}_{1} \%\right)$, forced expiratory flows in $50 \% \mathrm{VC}\left(\mathrm{FEV}_{50}\right)$, and markers of foundry workers' exposure and body burden, Al concentration in the breathing zone, blood and urine, biomarkers of the effects of exposure, concentration of CC16 and hyaluronic acid (HA) in serum were determined in all examined workers. Additional measurements comprised determinations of serum iron (Fe) levels, myeloperoxidase (MPO), eosinophil cationic protein (ECP), immunoglobulin E (IgE), glutathione S-transferase (GST), and superoxide dismutase (SOD) activity in erythrocytes. Results: The group of casting smelters was characterized by the highest levels of aluminum in urine (Al-U) ( $\left.43.7 \mu \mathrm{g} \mathrm{L}^{-1}\right)$, high levels of MPO, ECP and IgE, high SOD activity, low CC16 levels, and low activity of GST. Lower Al-U excretion was observed in locksmiths $\left(35.2 \mu \mathrm{g} \mathrm{L}^{-1}\right)$ and sawyers $\left(21.7 \mu \mathrm{g} \mathrm{L}^{-1}\right)$. Serum CC16 proved to be the most sensitive biomarker, showing high inverse relationship with serum $\mathrm{Al}(\mathrm{Al}-\mathrm{S})$ concentrations in casting smelters $(\mathrm{p}=0.006)$. Conclusions: The study showed that in conditions of occupational exposure, dusts containing $\mathrm{Al}_{2} \mathrm{O}_{3}<1 \mathrm{mg} \mathrm{m}^{-3}$ cause changes in the respiratory system and biomarkers in serum, especially in CC16, connected with altered functioning of this system. Changes in concentrations of the examined biomarkers and also in respiratory parameters of the study subjects were observed when Al-U concentration was $>40 \mu \mathrm{g} \mathrm{L}-1$.
\end{abstract}

Key words:

Clara cell protein, Aluminum, Respiratory system, Foundry, Occupational exposure

\section{INTRODUCTION}

Aluminum ( $\mathrm{Al})$ production is evidently associated with decreasing pulmonary function parameters [1] and the development of occupational asthma and fibrosis [2-9]. Several clinical and spirometric effects were ascertained in the exposed people [10,11]. At present, there is no clear consensus on appropriate methodology for the assessment of the risk of occupational $\mathrm{Al}$ exposure. To protect workers from detrimental effects of $\mathrm{Al}$ exposure, values of hygiene standards have been established in many countries;

This study was supported by the Polish State Committee for Scientific Research (Grant PB 725/P05/2000/18).

Received: August 25, 2006. Accepted: November 8, 2006.

Address reprint requests to Dr T. Hałatek, Department of Toxicology and Carcinogenesis, Nofer Institute of Occupational Medicine, św. Teresy 8, 91-348 Łódź, Poland (e-mail: halatek@imp.lodz.pl). 
unfortunately, they considerably differ between individual countries. Referring to the effect at low dose levels, the health base exposure limits are assumed to workplace occupational limit values (TLV) in the range from 2.0 to 10 $\mathrm{mg} \mathrm{m}^{-3}$, depending on the chemical form of $\mathrm{Al} \mathrm{[12].} \mathrm{Also}$ the application of biomarkers linked to toxic mechanisms in the process of risk assessment is very important [13]. Airway inflammation is a central feature of exposure to $\mathrm{Al}$ potroom emissions and induces pathological alterations, such as potroom asthma, similar to those described in other types of asthma. This kind of exposure affects the bronchiole-alveolar epithelium as the primary target site, causing lung injury. As a cell-specific marker for non-ciliated bronchiolar epithelial cells, which play a part in immunomodulatory and/or anti-inflammatory processes, assessment of Clara cell protein in serum (CC16) was proposed by various authors [14-17]. Recent studies on humans and rats have shown that $\mathrm{CC} 16$ is a sensitive biomarker of respiratory epithelial injury in exposures to welder fumes, glutaraldehyde, nitric oxides, or Al foundry dusts [18-23]. Clara cell proteins are involved in the pathogenic mechanisms leading to fibrosis [15,24], chronic obstructive pulmonary disease (COPD) [25,26], and asthma in humans [27-29] and in murine asthma model [30,31]. Low level of CC16 was observed in serum and bronchoalveolar lavage fluid (BAL) of active smokers [32].

A number of works described changes in the respiratory system without reference to the impact of Al concentration in the ambient air [9,33-38]. Rare studies reported changes in the respiratory system related to $\mathrm{Al}$ concentration in serum (Al-S) or urine (Al-U) [39,40], however, without any reference to biomarkers. A few authors give values of $\mathrm{Al}$ concentrations in urine and serum with reference to concentrations in the ambient air [1,41-43].

The aim of our study was to perform: 1) spirometric assessment of lung function, including determinations of forced volume capacity (FVC), forced expiratory volume in $1 \mathrm{~s}\left(\mathrm{FEV}_{1}\right), \mathrm{FEV}_{1} \%$ (Tiffenau index), forced expiratory flow in 50\% VC $\left.\left(\mathrm{FEF}_{50}\right) ; 2\right)$ determination of biomarkers in serum (CC16, serum iron (Fe-S), hyaluronic acid (HA), myeloperoxidase (MPO), eosinophil cationic protein (ECP) and immunoglobulin E (IgE) and in erythro- cytes (activity levels in superoxide dismutase (SOD) and glutathione S-transferase (GST)) of the exposed people, with reference to changes in the respiratory system; and 3) determination of the relationships between $\mathrm{Al}$ biomarkers and concentrations in the workplace atmosphere and $\mathrm{Al}$ body burden, Al-U and Al-S.

The study design was approved by the Regional Bioethical Committee of the Nofer Institute of Occupational Medicine in Łodź and complied with the current law in Poland. The examined subjects were informed of the scope and purpose of the examinations and their informed consent was obtained.

\section{MATERIALS AND METHODS}

\section{Subjects and study design}

The study groups included 66 male workers, including 50 casting smelters, 5 locksmiths, 11 sawyers and auxiliary workers, and the control group included 42 non-exposed people. All groups were matched for age, period of employment and smoking habit. Markers of exposure of the foundry workers (Al concentrations in air, blood and urine), biomarkers of the effect of exposure (concentration of $\mathrm{CC} 16$ and HA in serum), and respiratory functional tests were determined in all examined workers.

\section{Sampling and metal determination}

Personal air sampling at the breathing zone was applied (Casella AFC-123, flow rate $2 \mathrm{l} / \mathrm{min}$ ). Total dust was collected (over a period of about a 7-h shift) on membrane filter (Sartorius 111304, $0.8 \mu \mathrm{m}, \varnothing 32 \mathrm{~mm}$ ). In the sample collected on the filter, total dust was determined gravimetrically and $\mathrm{Al}$ concentration measured by flame atomic absorption spectrometry (using a Varian SpectrAA 250 atomic spectrometer).

Blood was drawn into red-top Vacutainers (Becton-Dickinson, $\mathrm{NJ}$ ) and allowed to stand at room temperature for $3 \mathrm{~h}$ to facilitate clotting. It was then refrigerated at $4^{\circ} \mathrm{C}$ until centrifugation, almost always within a few hours. Serum was transferred into two polyethylene $4.5 \mathrm{ml}$ Cryotubes and stored at $-20^{\circ} \mathrm{C}$ until determination. For erythrocytes isolation green-top Vacutainers Lith/Heparin were used. 
After centrifugation supernatants containing plasma and leukocytes were removed and red blood cells (RBC) were washed three times with saline, $\mathrm{RBC}$ were suspended in saline and stored at $-20^{\circ} \mathrm{C}$ until determination.

Aluminum in serum was determined by graphite furnace atomic absorption spectrophotometry using a Perkin-Elmer model 4100 ZL Zeeman unit with an autosampler AS-70 and computer data station PE 6200. The precision (coefficient of variation, $\mathrm{CV}$ ) of the method for serum at 10-100 $\mu \mathrm{g} \mathrm{L}^{-1}$ and 25-200 $\mu \mathrm{g} \mathrm{L}^{-1}$ was 7.0 and 7.9\%, respectively, and for urine at $25-150 \mu \mathrm{g} \mathrm{L}^{-1}$ the corresponding value was $4.5 \%$. The accuracy of the method was verified by analyzing serum and urine reference material (Seronorm ${ }^{\text {TM }}$ Trace Elements, No. 704121). The German Interlaboratory Comparison Program was used for the validation of the reliability of the analytical results [44].

Iron in serum was determined by spectrophotometry by measuring pink complexes of ferrous ion with a FeroZine unit, Alpha Diagnostic, Warsaw [45].

\section{Biochemical determinations}

Clara cell protein was determined by latex immunoassay (LIA) [46,47]. Specific rabbit antibody against CC16/Protein 1 from Dako A/S, Denmark was used. To eliminate possible interference (from complement, chylomicrons), the serum samples for CC16 estimation were pre-treated by heating at $56^{\circ} \mathrm{C}$ for $30 \mathrm{~min}$ and by the addition of polyethylene glycol $600(16 \%, \mathrm{v} / \mathrm{v} 1 / 1)$ and trichloroacetic acid $(10 \%, \mathrm{v} / \mathrm{v} 1 / 40)$. After overnight precipitation, the samples were centrifuged and CC16 was determined in supernatants. Serum HA was measured by enzymatic-immunoassay (ELISA), which uses a capture molecule, hyaluronic acid binding protein (HABP) from Chungai Diagnostics Science Co. Ltd. (Tokyo, Japan). GST ( $\left.\mathrm{U} \mathrm{mg}^{-1} \mathrm{Hb}\right)$ in RBC was determined according to the Habig method with CDNB as a substrate [48]. SOD activity $\left(\mathrm{U} \mathrm{mg}^{-1} \mathrm{Hb}\right)$ in RBC was assayed according to Beauchamp and Fridovich [49] with xantine oxidase and nitroblue tetrasolium salt. Mieloperoxidase quantitative radioimmunoassay was done in human serum with use of Pharmacia MPO RIA set (Pharmacia and Upjohn, Diagnostics, Uppsala, Sweden) according to Hoffstein [50]. Fluoroenzymatic immunoas- say (FEIA) tests were performed to estimate eosinophil cationic protein (ECP) and IgE in serum with Pharmacia UniCAP ECP and Pharmacia UniCAP IgE (Pharmacia and Upjohn, Diagnostics, Uppsala, Sweden).

\section{Spirometry}

After medical follow-up examination, workers were subjected to respiratory function tests. FVC in standing position, $\mathrm{FEV}_{1}$, and $\mathrm{FEF}_{50}$ were measured in each exposed and non-exposed worker with use of a Satellite DPU-411 Type II (USA) electronic apparatus with digital readout. Spirometric measurements were taken after an 8-h work shift prior to collection of urine and blood samples. Of the three consecutive measurements, the best results for a given person were selected for further analysis. In addition, $\mathrm{FEV}_{1} \%$ (Tiffeneau index) was calculated. For each worker, the observed values of ventilation parameters were expressed as a percentage of the predicted values calculated according to the subject's gender, age, weight, and height.

\section{Statistical analysis}

The characteristic parameters of the foundry workers by workplace and of controls were shown as means and its SD. Smoking habit among workers was presented as the percentage of the whole study group. Correlations between values were analyzed by Spearman's partial rankorder analysis. Significance was assigned at $p<0.05$. The differences between means for the groups selected were tested by the analysis of variance and multiple comparison procedure. We used Dunn's test for this purpose. The parameters with a skew distortion were transformed logarithmically. The relationship between continuous variables was determined by multiple linear regression. All variables were entered into the regression model (enter method). STATA 8 software was used for the statistical analysis.

\section{RESULTS}

Table 1 summarizes characteristics of $\mathrm{Al}$ foundry male workers and the level of exposure to $\mathrm{Al}_{2} \mathrm{O}_{3}$ at the breathing zone by workposts. The smelters had the shortest 
time of employment and the lowest levels of alumina in the breathing zone. In all groups, the percentage of active smokers did not exceed 50\%. Figure 1 presents the categories of workers exposed in the Aluminum Foundry Casting Department and smelters classified according to the smoking habit.

Figure 2 shows the correlation between total dust and $\mathrm{Al}_{2} \mathrm{O}_{3}$ in the workers' breathing zones. Results of spirometric examinations show slight changes, such as lower levels of spirometric indices in foundry workers as com-

Table 1. Characteristics of the aluminum foundry workers and levels of exposure to $\mathrm{Al}_{2} \mathrm{O}_{3}$ in the workpost breathing zones

\begin{tabular}{lcccc}
\hline & \multicolumn{4}{c}{ Aluminum foundry workers } \\
\cline { 2 - 4 } \multicolumn{1}{c}{ Variables } & $\begin{array}{c}\text { Smelters } \\
(\mathrm{n}=50)\end{array}$ & $\begin{array}{c}\text { Locksmiths } \\
(\mathrm{n}=5)\end{array}$ & $\begin{array}{c}\text { Sawers } \\
\text { anxiliary } \\
\text { workers } \\
(\mathrm{n}=11)\end{array}$ & $\begin{array}{c}\text { Controls } \\
(\mathrm{n}=42)\end{array}$ \\
\hline Age (years) & $38.9 \pm 5.9$ & $51.0 \pm 1.9$ & $37.4 \pm 9.3$ & $41.5 \pm 11.1$ \\
$\begin{array}{l}\text { Employment duration } \\
\text { (years) }\end{array}$ & $14.8 \pm 8.0$ & $28.4 \pm 2.0$ & $15.8 \pm 7.8$ & $20.9 \pm 10.9$ \\
$\begin{array}{l}\text { Exposure to } \mathrm{Al}_{2} \mathrm{O}_{3} \\
\left.\text { (mg m }{ }^{-3}\right)\end{array}$ & $0.32 \pm 0.18$ & $0.41 \pm 0.18$ & $0.61 \pm 0.63$ & - \\
$\begin{array}{l}\text { Cigarette smoking } \\
\text { (pack/years) }\end{array}$ & $16.5 \pm 10.8$ & $18.0 \pm 4.0$ & $7.7 \pm 4.4$ & $20.5 \pm 11.7$ \\
Smoking habits $(\%)$ & & & & \\
Non-smokers & 30.6 & 40.0 & 41.7 & 26.2 \\
Ex-smokers & 14.3 & 20.0 & 8.3 & 14.3 \\
Passive smokers & 10.2 & 0 & 8.3 & 7.2 \\
Current smokers & 44.9 & 40.0 & 41.7 & 52.3 \\
\hline
\end{tabular}

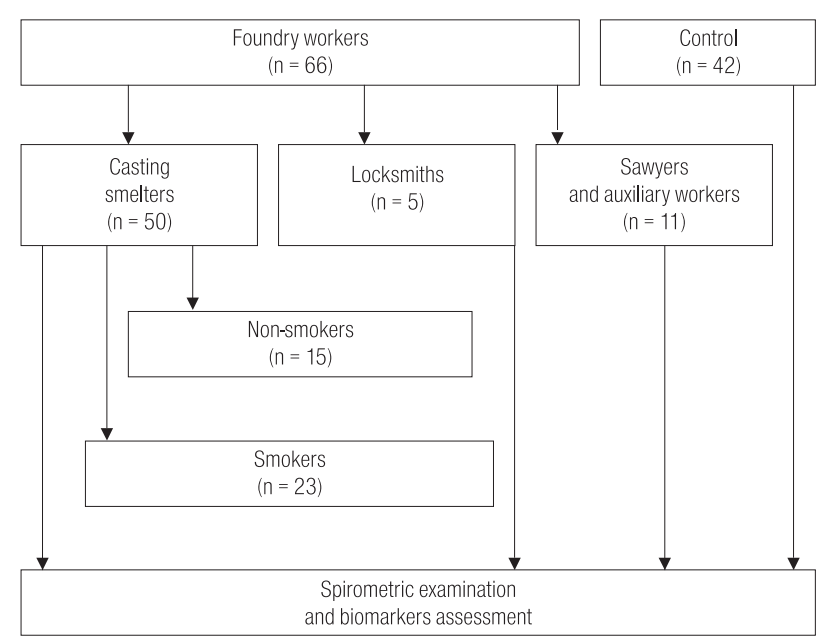

Fig. 1. Flowchart of spirometric and biochemical examinations of the aluminum foundry workers. pared to controls (Table 2). Those changes were dependent on the age and employment duration. Low levels of $\mathrm{FEV}_{1}, \mathrm{FEV}_{1} \%$ (Tiffenau index), and $\mathrm{FEF}_{50}$ were found in locksmiths, the oldest group of workers employed in the foundry. Evident detrimental effects of the air pollutants on the respiratory function, expressed by spirometric FVC, $\mathrm{FEV}_{1}$ and $\mathrm{FEF}_{50}$ values, could be noted in smelters as comapred to sawyers group with comparable age and employment duration and percent values of active smokers. The relation between the results of spirometric digital automatic pattern of pulmonary functional changes, enabling determination of the extent of obstruction, shows the highest degree of obstruction related to the increased $\mathrm{Al}$ concentration (expressed as $\mathrm{Al}_{2} \mathrm{O}_{3}$ ) in the ambient air (Fig. 3). After having arbitrarily divided smelters into three groups according to the level of $\mathrm{Al}_{2} \mathrm{O}_{3}$ in the air with mean values $\mathrm{x}_{\mathrm{a}}=0.2, \mathrm{x}_{\mathrm{a}}=0.3, \mathrm{x}_{\mathrm{a}}=$ $0.45 \mathrm{mg} / \mathrm{m}^{3}$, results of spirometric examinations (normal - very slight obstruction - mild to moderate obstruction) were specified separately for each of the three exposure

Table 2. Spirometric characteristics of aluminum foundry workers, $\%$ of predicted values

\begin{tabular}{lcccc}
\hline & \multicolumn{3}{c}{ Aluminum foundry workers } & \\
\cline { 2 - 4 } Variables & $\begin{array}{c}\text { Smelters } \\
(\mathrm{n}=50)\end{array}$ & $\begin{array}{c}\text { Locksmiths } \\
(\mathrm{n}=5)\end{array}$ & $\begin{array}{c}\text { Sawyers and } \\
\text { auxiliary } \\
\text { workers } \\
(\mathrm{n}=11)\end{array}$ & $\begin{array}{c}\text { Controls } \\
(\mathrm{n}=42)\end{array}$ \\
\hline $\mathrm{FVC}$ & $98.0 \pm 15.5$ & $112.7 \pm 22.0$ & $104.3 \pm 17.1$ & $99.6 \pm 14.8$ \\
$\mathrm{FEV}_{1}$ & $89.6 \pm 15.7$ & $82.7 \pm 9.5$ & $98.8 \pm 16.8$ & $91.3 \pm 18.7$ \\
$\mathrm{FEV}_{1} \%$ & $91.2 \pm 9.1$ & $78.7 \pm 16.1$ & $94.0 \pm 4.8$ & $91.7 \pm 11.4$ \\
$\mathrm{FEF}_{50}$ & $80.4 \pm 29.5$ & $69.0 \pm 17.3$ & $95.6 \pm 32.8$ & $83.7 \pm 27.6$ \\
\hline
\end{tabular}

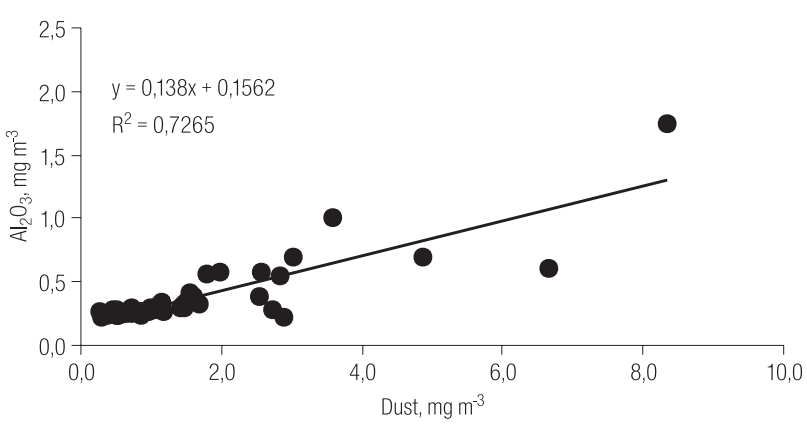

Fig. 2. Correlation between quantity of total dust and alumina $\left(\mathrm{Al}_{2} \mathrm{O}_{3}\right)$ levels in the breathing zone of all foundry workers (collected during an 8-h shift). 


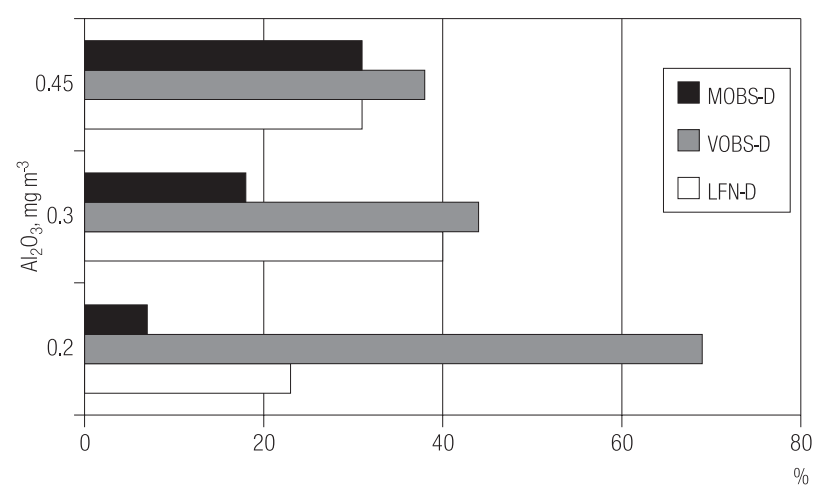

Fig. 3. The effects of $\mathrm{Al}_{2} \mathrm{O}_{3}$ in the breathing zone atmosphere on the pulmonary function. Changes in the lung function were determined separately for each of the three [low, $\mathrm{x}_{\mathrm{a}}=0.2 \mathrm{Al}_{2} \mathrm{O}_{3} \mathrm{mg} \mathrm{m}^{-3}(\mathrm{~N}=15)$; medium, $\mathrm{x}_{\mathrm{a}}=0.3 \mathrm{Al}_{2} \mathrm{O}_{3} \mathrm{mg} \mathrm{m}^{-3}(\mathrm{~N}=17)$; high, $\mathrm{x}_{\mathrm{a}}=0.45(\mathrm{~N}=18)$ $\mathrm{Al}_{2} \mathrm{O}_{3} \mathrm{mg} \mathrm{m}^{-3}$ ] exposure levels in arbitrarily determined smelter groups. The values specified in the figure represent the proportion of workers $(\%)$ who experienced one of three specified modes of lung function obstruction [normal (LFN-D), very slight obstruction (VOBS-D), and mild or moderate obstruction (MOBS-D)] in each group of the exposed smelters (with low, medium and high $\mathrm{Al}_{2} \mathrm{O}_{3}$ levels in breath zone during an 8-h shift). D - digital automatic pattern of pulmonary functional changes.

Table 3. Levels of Clara cell protein (CC16) and hyaluronic acid (HA) in serum and alumin in urine (Al-U) in alumin foundry workers and controls

\begin{tabular}{ccccc}
\hline & \multicolumn{3}{c}{ Aluminum foundry workers } & \\
\cline { 2 - 3 } Variables & \multicolumn{3}{c}{ Sawyers and } & Controls \\
& $\begin{array}{c}\text { Smelters } \\
(\mathrm{n}=50)\end{array}$ & $\begin{array}{c}\text { Locksmiths } \\
(\mathrm{n}=5)\end{array}$ & $\begin{array}{c}\text { auxiliary } \\
\text { workers } \\
(\mathrm{n}=11)\end{array}$ \\
& & & & \\
& & & & \\
\hline
\end{tabular}

\section{In serum:}

CC16, $\mu \mathrm{g} \mathrm{L}^{-1} \quad 11.9 \pm 2.34^{*} \quad 15.8 \pm 5.2 \quad 12.7 \pm 3.7 \quad 15.4 \pm 3.0$

$\mathrm{HA}, \mu \mathrm{g} \mathrm{L}^{-1} \quad 23.4 \pm 35.6 \quad 37.3 \pm 18.2 \quad 8.2 \pm 7.0 \quad 16.5 \pm 13.2$

Al-S, $\mu \mathrm{g} \mathrm{L}{ }^{-1} \quad 1.3 \pm 1.1 \quad 1.16 \pm 0.6 \quad 1.6 \pm 1.2 \quad 1.2 \pm 1.1$

In urine:

\begin{tabular}{lllll}
$\mathrm{Al}-\mathrm{U}, \mu \mathrm{g} \mathrm{L} \mathrm{L}^{-1}$ & $43.7 \pm 23.7^{*}$ & $35.2 \pm 12.4$ & $21.7 \pm 7.4$ & $10.2 \pm 7.7$ \\
\hline
\end{tabular}

* Statistically different from controls, $\mathrm{p}<0.05$

groups of casting smelters. Mild or moderate obstruction was most frequent in the $0.45 \mathrm{Al}_{2} \mathrm{O}_{3} \mathrm{mg} \mathrm{m}^{-3}$ group.

Table 3 shows the studied biomarkers: CC16, HA serum levels, Al-S and Al-U in casting smelters, locksmiths and sawyers in relation to control subjects. The group of smelters was characterized by the highest Al-U levels (43.7 $\left.\mu \mathrm{g} \mathrm{L}^{-1}\right)$ and the lowest serum CC16 levels. Locksmiths and sawyers showed $\mathrm{Al}-\mathrm{U}$ levels respectively three and two times higher than controls.
Figure 4 represents a schematic comparison of changes of all study biomarkers in the casting smelter, locksmith and sawyer groups. The figure shows serum levels of CC16, Al-S, Fe-S, HA, MPO, ECP and IgE and erythrocyte SOD and GST activity in different exposed groups in terms of percent values in respective controls. The group of smelters was characterized by statistically significantly elevated SOD activity, high MPO level, the lowest CC16 levels, the highest, although statistically insignificant, IgE levels, and the lowest GST activity. In the locksmiths, the oldest group of workers, most characteristic changes were: high HA level, a marker of inflammatory condition; however, the MPO marker of neutrophil activity was not changed. The sawyers exposed to high $\mathrm{Al}$ concentrations (expressed as $\mathrm{Al}_{2} \mathrm{O}_{3}$ ) in the air presented low $\mathrm{CC} 16$ levels, while the levels of other biomarkers were comparable to controls (Table 1).

It is worth noting that the smelter group presented high Spearman correlation coefficients between different biomarkers both in smoking and non-smoking smelters (Table 4). The set of biomarkers selected for this study confirmed their importance for studying the respiratory system in casting smelters. In Spearman analysis of smokers, serum CC16 correlated negatively with Al-S, and IgE. Al-S in smokers correlated negatively also with $\mathrm{HA}$ and $\mathrm{Fe}$.

Non-smokers showed high values of the correlation coefficient between $\mathrm{Al}-\mathrm{U}$ and Fe-S concentrations and spirometric indicators. In non-smoking casting smelters, low Fe levels correlated with decreased pulmonary function and higher MPO and IgE levels.

To eliminate the effects of confounding parameters, such as smoking and age of the smelters, linear regression analysis was applied for markers of exposure $-\mathrm{Al}_{2} \mathrm{O}_{3}$ in air, and $\mathrm{Al}-\mathrm{U}$ and $\mathrm{Al}-\mathrm{S}$ concentrations in relation to spirometric indices $\left(\mathrm{FVC}, \mathrm{FEV}_{1}\right.$ ) and serum CC16 (Table 5). Al-U levels, a marker of body burden and toxicity, showed a significant inverse correlation with FVC and $\mathrm{FEV}_{1}$. Strong negative correlation was found to occur between Al-S and CC16 in serum, the most characteristic change in casting smelters $(p=0.006)$. 

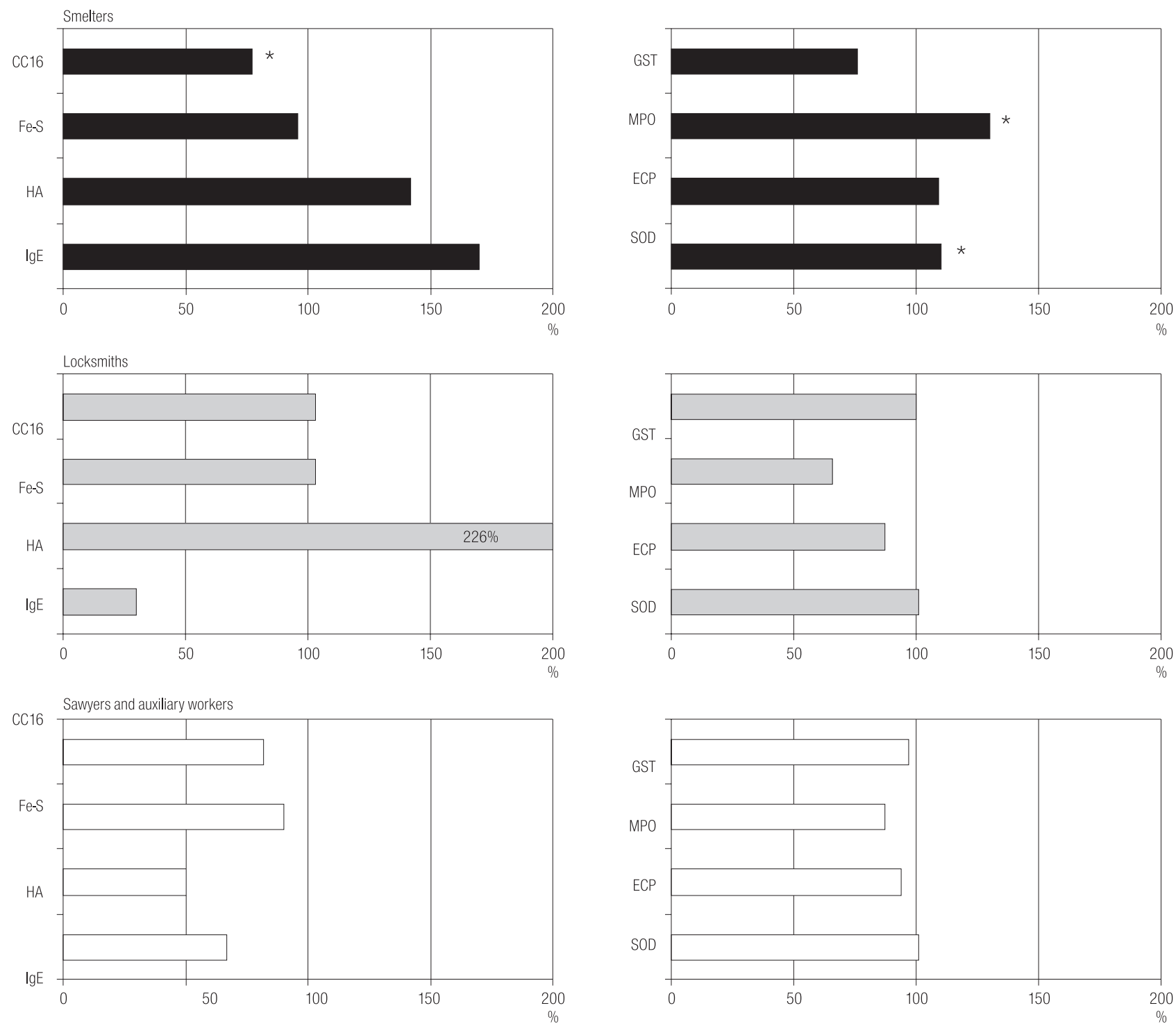

$* \mathrm{p}<0.05$.

Percent values for the exposed group vs. controls

Fig. 4. Biomarker levels in serum of the smelters $(n=50)$, locksmiths $(n=5)$, sawyers and auxiliary workers $(n=11)$ in terms of percent values for respective controls $(n=42)$.

Table 4. Spearman analysis between biomarkers in serum and urine and spirometric indices in smoking $(\mathrm{n}=23)$ and non-smoking $\left({ }^{*}\right)$ smelters $(\mathrm{n}=15)$

\begin{tabular}{|c|c|c|c|c|c|c|c|c|}
\hline $\begin{array}{c}\text { Correlation } \\
\text { coefficients }(\mathrm{p})\end{array}$ & $\begin{array}{l}\mathrm{CC} 16 \\
\left(\mu \mathrm{g} \mathrm{L} \mathrm{L}^{-1}\right)\end{array}$ & $\begin{array}{c}\mathrm{HA} \\
\left(\mu \mathrm{g} \mathrm{L}^{-1}\right)\end{array}$ & $\begin{array}{c}\mathrm{Fe} \\
\left(\mathrm{mg} \mathrm{dL}^{-1}\right)\end{array}$ & $\begin{array}{c}\operatorname{IgE} \\
\left(\mathrm{kU}^{-1} \mathrm{~L}\right)\end{array}$ & $\begin{array}{c}\text { MPO } \\
\left(\mu \mathrm{g} \mathrm{L}^{-1}\right)\end{array}$ & $\begin{array}{l}\text { FVC } \\
(\%)\end{array}$ & $\begin{array}{l}\mathrm{FEV}_{1} \\
(\%)\end{array}$ & $\begin{array}{l}\mathrm{FEF}_{50} \\
(\%)\end{array}$ \\
\hline $\mathrm{CC} 16$ & - & $\begin{array}{c}0.51 \\
(0.05)\end{array}$ & & $\begin{array}{l}-0.58 \\
(0.02)\end{array}$ & & & & \\
\hline Al-S & $\begin{array}{l}-0.54 \\
(0.03)\end{array}$ & $\begin{array}{l}-0.47 \\
(0.03)\end{array}$ & $\begin{array}{l}-0.54 \\
(0.02)\end{array}$ & & & & & \\
\hline $\mathrm{Al}-\mathrm{U}$ & & & $\begin{array}{c}0.60^{*} \\
(0.05)\end{array}$ & & & $\begin{array}{c}0.69^{*} \\
(0.01)\end{array}$ & $\begin{array}{c}0.76^{*} \\
(0.00)\end{array}$ & \\
\hline $\mathrm{Fe}$ & & & & $\begin{array}{c}-0.56^{*} \\
(0.05)\end{array}$ & $\begin{array}{l}-0.61^{*} \\
(0.01)\end{array}$ & & $\begin{array}{c}0.83^{*} \\
(0.00)\end{array}$ & $\begin{array}{r}0.76^{*} \\
(0.02)\end{array}$ \\
\hline HA & $\begin{array}{c}0.51 \\
(0.05)\end{array}$ & - & & & $\begin{array}{r}0.70^{*} \\
(0.00)\end{array}$ & & & \\
\hline
\end{tabular}


Table 5. Multiple linear regression of $\mathrm{Al}_{2} \mathrm{O}_{3}, \mathrm{Al}-\mathrm{U}$ and spirometric parameters $\left(\mathrm{FVC}\right.$ and $\left.\mathrm{FEV}_{1}\right)$ and $\mathrm{Al}-\mathrm{S}$ between Clara cell protein in serum of aluminum smelters $(n=50)$

\begin{tabular}{ccccl}
\hline Variables & Coefficient & $95 \%$ & $\mathrm{CI}$ & $\mathrm{P}$ \\
\hline Log $\mathrm{Al}_{2} \mathrm{O}_{3}(\mathrm{FVC})$ & 10.004 & -1.779 & 0.447 & $0.047^{*}$ \\
Non- smoking & 1.311 & -1.769 & 2.054 & 0.823 \\
Smoking & 6.890 & -4.204 & 0.386 & 0.190 \\
Log Al-U (FVC) & -9.672 & -1.779 & 0.447 & $0.019^{*}$ \\
Non- smoking & 0.142 & -1.769 & 2.054 & 0.403 \\
Smoking & -2.295 & -4.204 & 0.386 & 0.076 \\
Log Al-U (FEV $)$ & -8.772 & -1.779 & 0.447 & $0.039^{*}$ \\
Non- smoking & 0.142 & -1.769 & 2.054 & $0.040^{*}$ \\
Smoking & -2.295 & -4.204 & 0.386 & 0.276 \\
Log Al-S (CC16) & -1.113 & -1.779 & 0.447 & $0.006^{*}$ \\
Age & 0.055 & -0.031 & 0.141 & 0.232 \\
Non- smoking & 0.142 & -1.769 & 2.054 & 0.886 \\
Smoking & -2.295 & -4.204 & 0.386 & $0.035^{*}$ \\
\hline
\end{tabular}

* Statistically significant

\section{DISCUSSION}

According to WHO Environmental Health Criteria 210 [51] for considerably toxic effects at various dose levels, the dose range of interest is generally the lower dose range, since it usually reflects the human exposure situations. Several authors report respiratory $\mathrm{Al}$ health effects in workers [34,35,37,38]. Although some of the exposures in Al smelting have been well characterized, particularly in potrooms, little has been published regarding exposures in other $\mathrm{Al}$ production departments [52]. In several studies, attention was focused on polycyclic aromatic hydrocarbon (PAH) biomarkers in the $\mathrm{Al}$ industry [53-55].

The differences in the results of spirometric lung assessment are connected with concentration of dust and $\mathrm{Al}_{2} \mathrm{O}_{3}$ in relation to particular jobs. In our study in the Aluminum Foundry Casting Department, it was shown that $\mathrm{Al}_{2} \mathrm{O}_{3}$ concentrations observed at workplaces can cause various functional respiratory impairments (Tables 1 and 2), depending on the obstruction severity pattern (Fig. 3) and variation of biomarker levels referred to $\mathrm{Al}-\mathrm{S}$ and $\mathrm{Al}-\mathrm{U}$ in relation to particular jobs (Table 3, Fig. 4). In the groups exposed to foundry dust and fumes, the prevalence of Al-U levels exceeding $40 \mu \mathrm{g} \mathrm{L}^{-1}$ was markedly higher in smelters than in the control group (Table 3). Although not well-defined,
$\mathrm{Al}-\mathrm{S}$ and $\mathrm{Al}-\mathrm{U}$ concentrations are presumed to be related to the total body burden. In study performed by Rihimaki [56], daily fluctuation of Al-S was observed, where the urinary excretion of current $\mathrm{Al}$ uptake was more protracted. In the study by Elinder [57] for low-level Al exposure (below $0.5 \mathrm{mg} / \mathrm{m}^{3}$ ), these indicators (especially Al-U) make it possible to distinguish the exposed groups from the general population without, however, any clear relationship with various environmental $\mathrm{Al}$ concentrations. It was also seen that $\mathrm{Al}-\mathrm{U}$ increased with increasing work seniority and was more marked in certain processes, such as casting, and in the first few months or years of employment [42].

A relevant reduction of the spirometric indices of respiratory lung function (Table 2) accompanied by loss of serum CC16 levels and low GST activity with increasing SOD activity and high MPO, IgE and ECP levels in smelters (Fig. 4) exposed to $\mathrm{Al}_{2} \mathrm{O}_{3}$ at $0.3 \mathrm{mg} / \mathrm{m}^{3}$ in the ambient air of the breathing zones (Table 1) is the most important result of our study.

According to Arsalane et al. [58], the higher penetrability of the barrier of bronchiolar epithelium and, finally, loss of $\mathrm{CC} 16$ and of other lung proteins, in combination with oxidative stress, can essentially affect the induction of toxic irritating condition in the lungs. In our study, significant increase in SOD was found in the smelters (Fig. 4), accompanied by loss of GST activity; these findings suggest an oxidative stress due to increased free radicals. It is recognized that the pulmonary function and $\mathrm{CC} 16$ are affected also by PAH found in the smelting room atmosphere [23,59]. In the study by Nadif [60], SOD activities are more closely related to recent exposure to high dust concentrations than to the cumulative exposure and could be considered for use as a biological marker of exposure. Our results, the first to refer to the workers exposed to $\mathrm{Al}$ foundry dusts, support evidence that $\mathrm{CC} 16$ plays a role in the modulation of pulmonary allergic inflammation. Several animal studies described the role of Clara cells in allergic airway inflammation [61,62]. However, the exact sequence of events leading to allergic inflammation is still unclear. Chen et al. [61] suggest that CC16 plays a role in limiting alveolar influx of inflammatory cells, particularly for eosinophils with significantly increased levels of Th2 cytokines IL-4, Il-5, Il-9, and Il-13. It has been shown that 
the activation of Th2 cells is sufficient for the induction of inflammation and chronic pathological changes associated with asthma [64]. The decrease in $\mathrm{CC16}$ and increase in MPO and SOD were statistically valid, when related to controls, in the group of smelters only (Fig. 4). In this group of workers, $\mathrm{IgE}$ was $150 \%$ higher than the levels found in controls. Increase in IgE and ECP is a characteristic parameter in diagnosing asthma [63]. The study by Monteserin et al. [65] showed that IgE-dependent mechanism might promote MPO released by neutrophils at allergic sites. In atopic asthmatic children, higher levels of IgE, MPO and ECP were observed [66]. In our study, statistically significant inverse correlation was found between CC16 and IgE in smoking smelters (Table 4). Statistically significant increase in IgE was found in smokers and former smokers in the group of smelters as compared to controls (data not shown), confirming adjuvant effects of smoking [67]. Animal studies showed that IgE were induced by Al hydroxide inhalation [68], or intratracheal instilation of Al silicate [69]. Shijubo et al. [27] showed significantly decreased proportions of CC16-positive epithelial cells in small airways of asthmatics. Increased MPO and ECP confirm the role of neutrophils and eosinophils in airway inflammation of potroom workers [70] and asthmatic patients [71]. Moreover, it was documented that eosinophilia might be an early subclinical marker indicating the risk of developing Al-induced lung disease [72]. Indeed, in other pulmonary diseases, eosinophilia has been shown to indicate rapid development of disease and impend fibrosis formation [73-75]. Figure 4 shows that serum HA marker of inflammatory condition or remodeling of lung tissues was increased in smelters together with the increased activity of neutrophils and eosinophils. Eklund [76] showed that BAL of potroom workers contained more fibronectin, albumin, and HA than the fluid of those non-exposed. Increased HA, MPO and ECP levels were found in the patients with chronic bronchitis [77]. HA was the only biomarker showing a distinct, although statistically insignificant, increase in the oldest locksmith workers (Table 3, Fig. 4), confirming marked age-dependence [78].

Lower iron levels, not statistically significant, were detected in serum of the smelters and sawyers (Fig. 4). Both those groups of workers had low levels of serum CC16. In the group of sawyers, signs of inflammations measured by the employed markers were not observed (Fig. 4). In Spearman's partial rank-order analysis (Table 4), Fe level correlated significantly (negatively) with Al-S of smelters (in active smokers) and positively with Al-U (in nonsmokers), confirming the effect of $\mathrm{Al}$ and $\mathrm{Fe}$ competition with transferrin (a transfer ligand) in serum [79,80]. In our study, we noted a negative correlation between IgE, MPO and Fe levels in non-smoking smelters, while dislocation of iron in chronic inflammation may be an additional factor affecting serum transferrin iron level [81] (Table 4). Al affects various stages of heme biosynthesis by changing the activity of some enzymes [82-85], iron metabolism [86-89] or disrupting erythrocyte membrane [90].

Linear regression analysis (Table 5), eliminating the effects of respective confounding factors (e.g., age, tobacco smoking) shows that $\mathrm{CC} 16$ and Al-S correlation was very strong $(p=0.006)$. It should be noted that this close relation supports the opinion that both markers (Al-S and CC16) are related, at least in part, to the daily fluctuation as already observed in cross-week CC16 evaluation in blood of shipyard welders and workers of a chemical plant exposed to nitric oxide [21,22]. Thus, inhibition of Clara cell protein secretion in smelters heavily exposed to $\mathrm{Al}$ can probably enhance Al-S levels by suppressing anti-inflammatory effect in the respiratory tract. Although the exact mechanism of the lung-blood transfer of $\mathrm{CC} 16$ remains to be clarified, it appears to be governed by a number of factors, among which the permeability of the tight bronchoalveolar epithelium seems to be most essential. The molecular features of the lung proteins and their exchangeable pool appear to be critical. Bearing all this in mind, it seems reasonable to believe that the aluminum indirectly interacts in the $\mathrm{CC} 16$ decrease via metal-related changes in the lipid matrix of the membrane [91-95].

In our study group (foundry department workers), only casting smelters showed Al-U levels significantly higher than in controls. In the study by Alesso [96], the mean $\mathrm{Al}-\mathrm{U}$ levels in a group of 227 subjects occupationally exposed to aluminum at $0.1-10.0 \mathrm{mg} / \mathrm{m}^{3}$ were higher than those of the reference population; however, Al-U levels of 
the workers were generally lower than $20 \mu \mathrm{g} \mathrm{L}{ }^{-1}$, which is the upper limit for the reference population.

The lowest dose which can cause impairment of human health is used in setting the hygiene standards; thus it is essential to determine experimentally the dose/effect parameters.

Current hygiene standards in the USA [12] allow several TLV levels, depending on the chemical form of Al. For alumina dust, TLV is $10 \mathrm{mg} \mathrm{m}^{-3}$, for welder fumes (as $\left.\mathrm{Al}\right) 5 \mathrm{mg} \mathrm{m}^{-3}$, and for dissolved salts (as Al) $2 \mathrm{mg} \mathrm{m}^{-3}$. In Germany, for metallic $\mathrm{Al}$ and alumina fumes, the level of MAK is $1.5 \mathrm{mg} \mathrm{m}^{-3}$ (respirable fraction) [97]. The Polish OEL value for $\mathrm{Al}_{2} \mathrm{O}_{3}$ has been set at $2.5 \mathrm{mg} \mathrm{m}^{-3}$ (as Al) and $1.2 \mathrm{mg} \mathrm{m}^{-3}$ (as Al) for respirable fraction [98]. The American Conference of Govermental Industrial Hygienists(ACGIH) has not proposed any level of BEI for $\mathrm{Al}$ in biological materials. In Germany, those levels are set at $200 \mu \mathrm{g} \mathrm{L}^{-1}$ in samples of urine collected after the end of work shift [97]. In Finland, BEI has been set at 160 $\mu \mathrm{g} \mathrm{L}^{-1}$ measured on Monday before work [99].

The most important observation in this study was reduction of spirometric indices and loss of CC16 levels in serum with statistically significant increase in MPO and SOD levels in smelters exposed to $\mathrm{Al}_{2} \mathrm{O}_{3}$ within the range $0.1-1.0 \mathrm{mg} \mathrm{m}^{-3}$ (the mean levels $\mathrm{x}_{\mathrm{a}}=0.3 \mathrm{mg} \mathrm{m}^{-3}$ ). Our results and those of several other authors $[43,96,100,101]$ show that an extensive study is needed to determine a more correct TLV and health-based permissible concentration for occupational exposure to $\mathrm{Al}$. Changes in and adverse effects on the central nervous system, for example, which can be observed at levels below the actual German and Finnish BEI standard for Al- $\mathrm{U}$ concentration in $\mathrm{Al}$ welders should be taken into account $[56,95]$. Future studies on respiratory morbidity should explore the interaction of mixtures, which may show a synergistic activity.

\section{CONCLUSIONS}

1. In conditions of occupational exposure, dusts containing $\mathrm{Al}_{2} \mathrm{O}_{3}<1 \mathrm{mg} \mathrm{m}^{-3}$ cause deterioration of the respiratory system and also changes of biomarkers in serum, associated with altered functioning of this system.
2. Clara cell protein (CC16) proved to be the most sensitive biomarker, showing high correlation with $\mathrm{Al}$ concentrations in serum of the smelters.

3. Changes in concentrations of the examined biomarkers and also in respiratory parameters of the study subjects were observed when the urinary Al concentration was $>40 \mu \mathrm{g} \mathrm{L} \mathrm{L}^{-1}$.

\section{ACKNOWLEDGEMENTS}

Thanks are due to G. Rażniewska, MSc. for Al determination in urine and serum, and B. Kur, MSc. for the measurement of IgE, MPO and ECP in serum. Special thanks are due to Ms. A. Kubiak for her participation in technical procedures and to Dr. W. Sobala for the statistical analysis of the results.

\section{REFERENCES}

1. Abbate C, Giorgianni C, Brecciaroli R, Tringali MA, D’Arrigo G. Spirometric function in non-smoking workers exposed to aluminum. Am J Ind Med 2003;44:400-4.

2. Abramson MJ, Włodarczyk JH, Saunders NA, Hensley MJ. Does aluminium smelting cause lung disease? State of the art. Am Rev Respir Dis 1998;139:1042-57.

3. Soyseth V, Kongerund J, Boe J, Fonneland T. Bronchial responsiveness and work-related asthma in aluminium potroom workers effect of removal from exposure. Europ Resp J 1992;5:829-33.

4. Kongerund J, Boe J, Soyseth V, Naalsund A, Magnus P. Aluminium potroom asthma: the Norvegian experience. Eur Resp J 1994;7: 165-72.

5. O'Donnell T. Asthma and respiratory problems - a review. Sci Total Environ 1995;163:137-45.

6. Sorgdrager B, de Looff AJ, de Monchy JG, Pal TM, Dubois AE, Rijcken B. Occurrence of occupational asthma in aluminium potroom workers in relation to preventive measures. Int Arch Occup Environ Health 1998;71:53-5.

7. Vandenplas O, Delwich JP, Vanblisen ML, Joly J, Roosels D. Occupational asthma caused by aluminium welding. Eur Respir J 1998; 11:1182-4.

8. Barnard CG, McBride DI, Firth HM, Herbison GP. Assessing individual employee risk factors for occupational asthma in primary aluminium smelting. Occup Environ Med 2004;61:604-8 
9. Sjaheim T, Halstensen TS, Lund MB, Bjortuft O, Drablos PA, Malterud D, et al. Airway inflammation in aluminium potroom asthma. Occup Environ Med 2004;61:779-85.

10. WHO. Aluminium. International Programme on Chemical Safety. Environmental Health Criteria 194. Geneve: World Health Organization; 1997.

11. Sjorgen B, Elinder CG, Iregren A, McLachlan DRC, Riihimaki V. Occupational aluminium exposure and its health effects. In: Yokel RA, Golub MS, editors. Reserch Issues in Aluminium Toxicity. USA: Toxicity Yaylor and Francis; 1997. pp. 165-183.

12. ACGIH. Threshold Limit Values for Chemical Substances and Physical Agents. Washington: American Conference of Governmental Industrial Hygienists; 2001.

13. WHO. Biomarkers and risk assessment: concepts and principles. International Programme on Chemical Safety. Environmental Health Criteria 155. Geneve: World Health Organization; 1993.

14. Mantile G, Miele L, Cordella-Miele E, Singh G, Katyal SL, Mukherjee AB. Human Clara cell 10-kDa protein is the counterpart of rabbit uteroglobin. J Biol Chem 1993;268:565-75.

15. Lesur O, Bernard A, Arsalane K, Lauwerys R, Begin R, Cantin A, et al. Clara cell protein (CC16) induces a Phospholipase A2-mediated inhibition of fibroblasts migration in vitro. Am J Respir Crit Care Med 1995;152:290-7.

16. Singh G, Katyal SL. Clara cells and Clara cell 10 kD protein (CC10). Am J Respir Cell Mol Biol 1997;17:141-3.

17. Hałatek T, Hermans C, Broeckaert F, Wattiez R, Wiedig M, Toubeau $\mathrm{G}$, et al.Quantification of Clara cell protein in rat and mouse biological fluids using a sensitive immunoassay. Eur Resp J 1998;11:726-33.

18. Hałatek T, Trzcinka-Ochocka M, Matczak W, Krajewska B. Studies on the relationship between occupational exposure to manganese and serum Clara cell protein levels in shipyard workers. Trace Elem Electrolytes 2000;17:48-53.

19. Hałatek T, Opalska B, Świercz R, Pałczyński C, Górski P, Rydzyński K, et al. Glutaraldehyde inhalation exposure of rats: Effects on morphology of the lungs and Clara cell protein and hyaluronic acid levels in BAL. Inhal Toxicol 2003;15:85-97.

20. Hałatek T, Opalska B, Węgrowski Y. Clara cell protein and metalloproteinase level in BALF after alumina dust-induced lung injury. In: Marone G, editor. Clinical Immunology and Allergy in Medicin. Naples, Italy: JGC Edition; 2003. pp. 307-11.

21. Hałatek T, Wrońska-Nofer T, Gruchała J, Trzcinka-Ochocka M, Stetkiewicz J, Rydzyński K. Pneumotoxic effects of welding fumes: Cross-week evaluation of Clara cell protein and manganese in blood of shipyard workers. Trace Elem Electrolytes 2004;21:16-22.
22. Hałatek T, Gromadzińska J, Wąsowicz W, Rydzyński K. Serum Clara cell protein and $\alpha_{2}$-microglobulin as early markers of occupational exposure to nitric oxides. Inhal Toxicol 2005;17:87-95.

23. Hałatek T, Opalska B, Lao I, Stetkiewicz J, Rydzyński K. Pneumotoxicity of dust from aluminum foundry and pure alumina: comparative morphological, and biomarkers study in rats Int J Occup Environ Health 2005;18:51-62.

24. Marimoto Y, Tanaka I. In vivo studies of man-made mineral fibersfibrosis-related factors. Ind Health 2001;39:106-13.

25. Pilette C, Godding V, Kiss R, Delos M, Verbeken E, Decaestecker C, et al. Reduced epithelial expression of secretory component in small airways correlates with airflow obstruction in chronic obstructive pulmonary disease. Am J Resp Crit Care Med 2001;163:185-94.

26. Ekberg-Jansson A, Andersson B, Bake B, Boijsen M, Enanden I, Rosengren A, et al. Neutrophil-associated activation markers in healthy smokers relates to a fall in $D L(C O)$ and to emphysematous changes on high resolution CT. Respir Med 2001;95:363-73.

27. Shijubo N, Itoh Y, Yamaguchi T, Imada A, Hirasawa M, Yamada T, et al. Clara cell protein-positive epithelial cells are reduced in small airways of asthmatics. Am J Respir Crit Care Med 1999;160:930-3.

28. Sharma S, Ghosh B. Association of an intragenic microsatellite marker in the CC16 gene with asthma in the Indian population. J Hum Genet 2004;49:677-83.

29. Ye Q, Fujita M, Ouchi H, Inoshima I, Maeyama T, Kuwano K, et al. Serum CC-10 in inflammatory lung diseases. Respiration 2004;71:505-10.

30. Reader JR, Tepper JS, Schelegle ES, Aldrich MC, Putney LF, Pfeiffer JW, et al. Pathogenesis of mucous cell metaplasia in a murine asthma model. Am J Pathol 2003;162:2069-78.

31. Hayashi T, Ishii A, Nakai S, Hasegawa K. Ultrastructure of goblet-cell metaplasia from Clara cell in the allergic asthmatic airway inflammation in a mouse model of asthma in vivo. Virchows Arch 2004;444:66-73.

32. Shijubo N, Itoh Y, Yamaguchi T, Shibuya Y, Morita Y, Hirasawa M, et al. Serum and BAL Clara cell $10 \mathrm{kDa}$ protein (CC 10) levels and CC 10-positive bronchiolar cells are decreased in smokers. Eur Respir J 1997;10:1108-14.

33. Field GB. Pulmonary function in aluminium smelters. Thorax 1984;39:743-51.

34. Saric M, Godnic-Cvar J, Gomzi M, Stilinovic L. The role of atopy in potroom workers' asthma. Am J Ind Med 1986;9:239-42.

35. Saric M, Marelja J. Bronchial hyperreactivity in potroom workers and prognosis after stopping exposure. Br J Ind Med 1991;48:653-5. 
36. Kilburn KH, Warshaw RH. Irregular opacities in the lung, occupational asthma, and airways dysfunction in aluminum workers. Am J Ind Med 1992;21:845-53.

37. San LN, Uysal H, Gokbel H, Bediz CS, Sayal A. Pulmonary function of workers in the aluminum industry. Am J Ind Med 1998;33:305-7.

38. Radon K, Nowak D, Heinrich-Ramm R, Szadkowski D. Respiratory health and fluoride exposure in different parts of the modern primary aluminum industry. Int Arch Occup Environ Health 1999;72: 297-303.

39. Soyseth V, Boe J, Kongerud T. Relation between decline in FEV ${ }_{1}$ and exposure to dust and tobacco smoke in aluminium potroom workers. Occup Environ Med 1997;54:27-31.

40. Kraus T, Schaller KH, Angerer J, Letzel S. Aluminium dust-induced lung disease in the pyro-powder-producing industry: detection by highresolution computed tomography. Int Arch Occup Environ Health 2000;73:61-4.

41. Sjogren B, Elinder CG, Lidums V, Chang G. Uptake and urinary excretion of aluminium among welders. Int Arch Occup Environ Health 1988;60:77-9.

42. Apostoli P, Lucchini R, Maccarrone R, Alessio L. Biological monitoring of occupational exposure to aluminum. Med Lav 1992;83: $475-83$.

43. Rollin HB, Theodorou P, Cantrell AC. Biological indicators of exposure to total and respirable aluminium dust fraction in a primary aluminium smelter. Occup Environ Med 1996;53:417-21.

44. Razniewska G, Trzcinka-Ochocka M. ET-AAS as a method for determination of aluminium in blood serum and urine. Chem Anal (Warsaw) 2003;48:107-13.

45. Zilva JR, Pannall PR. Iron metabolism in Clinical Chemistry in Diagnosis and Treatment. Lloyd-Luke Chap 1979;18:378-92.

46. Bernard A, Lauwerys R, Noel A, Vandeleene B, Lambert A. Determination by latex immunoassay of protein 1 in normal and pathological urine. Clin Chim Acta 1991;201:231-45.

47. Hałatek T, Jakubowski M. Latex-immunological method of determination of micromolecular proteins and albumin in urine. I. Description of the method. Med Pr 1991;42:77-88 [in Polish].

48. Habig W, Pabst MJ, Jacoby W. Glutathione S-transferase: the first step in mercapturic acid formation. J Biol Chem 1974;249:7130-9.

49. Beauchamp C, Fridovich I. Superoxide dismutase: improved assays and an assay applicable gels. Anal Biochem 1971;44:276-87.

50. Hoffstein ST. Intra- and extracellular secretion from polymorphonuclear leucocytes. Weissman G, editor. In: The Cell Biology of Inflammation. Amsterdam: Elsevier North Holland; 1980. pp. 387-430.

51. WHO. Principles for the assessment of risk to human health from exposure to chemicals. International Programme on Chemical Safety.
Environmental Health Criteria 210. Geneve: World Health Organization; 1999.

52. Sinkkonen S, Lahtipera M, Vattulainen A, Takhistov VV, Viktorovskii IV, Utsal VA, et al. Analyses of known and new types of polyhalogenated aromatic substances in oven ash from recycled aluminium production. Chemosphere 2003;52:761-75.

53. Jongeneelen FJ. Benchmark guideline for urinary 1-hydroxypyrene as biomarker of occupational exposure to polycyclic aromatic hydrocarbons. Ann Occup Hyg 2001;45:3-13.

54. Rappaport SM, Waidyanatha S, Serdar B. Naphthalene and its biomarkers as measures of occupational exposure to polycyclic aromatic hydrocarbons. J Environ Monit 2004;6:413-6.

55. Pavanello S, Clonfero E. Individual susceptibility to occupational carcinogens: the evidence from biomonitoring and molecular epidemiology studies. G Ital Med Lav Ergon 2004;26:311-21.

56. Riihimaki V, Hanninen H, Akita R, Kovala T, Kuosma E, Paakkulainen $\mathrm{H}$, et al. Body burden of aluminium in relation to central nervous system function among metal inert-gas welders. Scand J Work Environ Health 2000;26:118-23.

57. Elinder CG, Ahrengart L, Lidums V, Pettersson E, Sjogren B. Evidence of aluminium accumulation in aluminium welders. Br J Ind Med 1991;48:735-8.

58. Arsalane K, Broeckaert F, Knoops B, Clippe A, Buchet JP, Bernard A. Increased serum and urinary concentrations of lung clara cell protein in rats acutely exposed to ozone. Toxicol Appl Pharmacol 1999;159:169-74.

59. Bergamaschi E, Apostoli P, Catalani S, Festa D, Folesani G, Andreoli $\mathrm{R}$, et al. Indicators of pulmonary epithelial damage among workers at a foundry exposed to airborne pollutants. G Ital Med Lav Ergon 2003;25:104-6.

60. Nadif R, Bourgkard E, Dusch M, Bernadac P, Bertrand JP, Mur $\mathrm{JM}$, et al. Relations between occupational exposure to coal mine dusts, erythrocyte catalase and $\mathrm{Cu}^{++} / \mathrm{Zn}^{++}$superoxide dismutase activities, and the severity of coal workers' pneumoconiosis. Occup Environ Med 1998;55:533-40.

61. Chen LC, Hang Z, Myers AC, Huang SK. Cutting edge: Altered pulmonary eosinophilic inflammation in mice deficient for Clara cell secretory 10-kDa protein. J Immunol 2001;167:3025-8.

62. Quarcoo D, Schulte-Herbruggen O, Lommatzsch M, Schierhorn K, Hoyle GW, Renz H, et al. Nerve growth factor induces increased airway inflammation via a neuropeptide-dependent mechanism in a transgenic animal model of allergic airway inflammation. Clin Exp Allergy 2004;34:1146-51.

63. Renauld JC. New insights into the role of cytokines in asthma. J Clin Pathol 2001;54:577-89. 
64. Rossi RE, Monasterolo G. Prevalence of serum IgE antibodies to the Staphylococcus aureus enterotoxins (SAE, SEB, SEC, SED, TSST-1) in patients with persistent allergic rhinitis. Int Arch Allergy Immunol 2004;133:261-6.

65. Monteseirin J, Bonilla I, Camacho MJ, Conde J, Sobrino F. IgE-dependent release of myeloperoxidase by neutrophils from allergic patients. Clin Exp Allergy 2001;31:889-92.

66. Kristjansson S, Shimizu T, Strannegard IL, Wennergren G. Eosinophil cationic protein, myeloperoxidase and tryptase in children with asthma and atopic dermatitis. Pediatr Allergy Immunol 1994;5:223-9.

67. Nielsen GD, Olsen O, Larsen ST, Lovik M, Poulsen LK, Glue C, et al. IgE-mediated sensitisation, rhinits and asthma from occupational exposures. Smoking as a model for airborne adjuvants? Toxicology 2005;216:87-105.

68. Clausen SK, Bergqvist M, Poulsen LK, Poulsen OM, Nielsen GD. Development of sensitisation or tolerance following repeated OVA inhalation in BALB/cJ mice. Dose-dependency and modulation by the Al(OH)3 adjuvant. Toxicology 2003;184:51-68.

69. Fujimaki H, Ozawa M, Ashikawa T, Kubota K, Watanabe N. Induction of IgE antibody production to aerosolized ovalbumin in mice treated intratracheally with aluminum silicate. Int Arch Allergy Appl Immunol 1986;79:206-10.

70. Sorgdrager B, Pal TM, deLooff AJ, Dubois AE, deMonchy JG. Occupational asthma in aluminium potroom workers related to pre-employment eosinophil count. Eur Respir J 1995;8:1520-4.

71. Jatakanon A, Uasuf C, Maziak W, Lim S, Chung KF, Barnes PJ. Neutrophil inflammation in severe persistent asthma. Am J Resp Crit Care Med 1999;160:1532-9.

72. Schwarz Y, Kivity S, Fischbein A, Abraham JL, Fireman E, Moshe S, et al. Evaluation of workers exposed to dust containing hard metals and aluminum oxide. Am J Ind Med 1998;34:177-82.

73. Watters LC, Schwarz MI, Cherniack RM, Waldron JA, Dunn TL, Stanford RE, et al. Idiopathic pulmonary fibrosis. Pretreatment bronchoalveolar lavage cellular constituents and their relationships with lung histopathology and clinical response to therapy. Am Rev Respir Dis 1198;35:696-704.

74. Allen JN, Davis WB, Pacht ER. Diagnostic significance of increased bronchoalveolar lavage fluid eosinophils. Am Rev Respir Dis 1990;142:642-7.

75. Fujimoto K, Kubo K, Yamaguchi S, Honda T, Matsuzawa Y. Eosinophil activation in patients with pulmonary fibrosis. Chest 1995;108:48-54.

76. Eklund A, Arns R, Blaschke E, Hed J, Hjertquist SO, Larsson K, et al. Characteristic of alveolar cells and soluble components in bron- choalveolar lavage fluid from non-smoking aluminium potroom workers. Br J Ind Med 1989;46:782-6.

77. Riise GC, Ahlsedt S, Larsson S, Enander I, Jones I, Larsson P, et al. Bronchial inflammation in chronic bronchitis assessed by measurement of cell products in bronchial lavage fluid. Thorax 1995;50:360-5.

78. Werle E, Jakel HP, Muller A, Fischer H, Fiehn W, Eich W. Serum hyaluronic acid levels are elevated in arthritis patients, but normal and not associated with clinical data in patients with fibromyalgia syndrome. Clint Lab 2005;51:11-9.

79. Huang JY, Huang CC, Lim PS, Wu MS, Leu ML. Effect of body iron stores on serum aluminum level in hemodialysis patients. Nephron 1992;61:158-62.

80. Van Landegheim GF, D’Haese PC, Lamberts LV, De Broe ME. Competition of iron and aluminium for transferrin: the molecular basis for aluminium deposition in iron-overloaded dialysis patients? Exp Nephrol 1997;5:239-45.

81. Mutze S, Hebling U, Stremmel W, Wang J, Arnhold J, Pantopoulos K, et al. Myeloperoxidase-derived hypochlorous acid antagonizes the oxidative stress-mediated activation of iron regulatory protein 1. J Biol Chem 2003;278:40542-9.

82. Meredith PA, Moore MR, Goldberg A. Effects of aluminium, lead and zinc on delta-aminolaevulinic acid dehydratase. Enzyme 1977;22:22-7.

83. Bia MJ, Cooper K, Schnall S, Duffy T, Hendler E, Malluche H, et al. Aluminum induced anemia: pathogenesis and treatment in patients on chronic hemodialysis. Kidney Int 1989;36:852-8.

84. Rosenlof K, Fyhrquist F, Tenhunen R. Erythropoietin, aluminium, and anaemia in patients on haemodialysis. Lancet, 1999;335:247-9.

85. Chmielnicka J, Nasiadek M, Lewandowska-Zyndul E. The effect of aluminum chloride on some steps of heme biosynthesis in rats after oral exposure. Biol Trace Elem Res 1994; 40:127-36.

86. Drueke TB. Modulating factors in the hematopoietic response to erythropoietin. Am J Kidney Dis 1991;18:87-92.

87. Allain P, Leblondel G, Mauras Y. Effect of aluminum and deferoxamine on biliary iron elimination in the rat. Proc Soc Exp Biol Med 1988;188:471-3.

88. Nasiadek M, Chmielnicka J. Interaction of aluminum with exogenous and endogenous iron in the organism of rats. Ecotoxicol Environ Saf 2000;45:284-90.

89. Guo C., Huang CJ, Chiou YL, Hsu GS. Alteration of trace element distribution and testis $A C E$ activity in mice with high peritoneal aluminum. Biol Trace Elem Res 2002;86:145-57.

90. Bazzoni GB, Bollini AN, Hernandez GN, Contini-Mdel C, Chiarotto MM, Rasia ML. In vivo effect of aluminium upon the physical properties of the erythrocyte membrane. J Inorg Biochem 2005;99:822-7. 
91. Umland TC, Swaminathan S, Singh G, Warty V, Furey W, Pletcher $\mathrm{J}$, et al. Structure of a human Clara cell phospholipid-binding proteinligand complex at 1.9 A resolution. Nat Struct Biol 1994;8:538-45.

92. Haug A, Shi B, Vitorello V.Aluminium interactions with phosphoinositide-associated signal transduction. Arch Toxicol 1994;68:1-7.

93. Jones DI, Kochian LV. Aluminium interaction with plasma membrane lipids and enzyme metal binding sites and its potential role in $\mathrm{Al}$. Cytotoxicity FEBS Lett 1997;400:51-7.

94. Ibrahim AM, Funkhouser JD. Phoshatidylinositol transfer protein in lung: cellular and subcellular localization. J Histochem Cytochem 1997;45:551-8.

95. Halatek T, Sinczuk-Walczak H, Rydzynski K. Prognostic significance of low serum levels Clara cells phospholipid-binding protein in occupational aluminium neurotoxicity J Inorg Biochem 2005;99:1904-11.

96. Alessio L, Apostoli P, Ferioli A, Di Sipio I, Mussi I, Rigosa C, Albertini A. Behaviour of biological indicators of internal dose and some neuro-endocrine tests in aluminium workers. Med Lav 1989;80: 290-300.
97. Deutsche Forschungsgemeinschaft - List of MAK and BAT values 2003. Maximum concentration and biological tolerance values at the workplace. Weinheim: Wiley_VCH Verlag; 2003.

98. Ordinance of the minister of state economy and labour on the maximum permissible concentrations and intensities of harmful agents in the work environment. J Law Rep Poland 2005,212,1769 [in Polish].

99. Biomonitoring of exposure to chemicals [cited Aug 25, 2006]. Helsinki: Finnish Institute of Occupational Health; 1996. Available from http://www.ttl.fi.

100. Benke G, Abramson M, Sim M. Exposures in the alumina and primary aluminium industry: an historical review. Ann Occup Hyg 1989;42:173-89.

101. Westberg HB, Selden AI, Bellander T. Exposure to Chemical Agents inSwedishaluminumfoundriesandaluminumremeltingplants-Acomprehensive survey. Appl Occup Environ Hygiene 2001;16:66-77. 